\title{
Taking a tip from the past
}

\author{
Poison Arrows: The Amazing Story of How \\ Prozac and Anaesthetics Were Developed \\ From Deadly Jungle Poison Darts \\ by Stanley Feldman \\ Metro: 2005. 244 pp. £14.99
}

\section{John Carmody}

Who would have thought that such a small book could contain so many errors? These are not the errors that a pernickety specialist dutifully finds in a popular account of a complex scientific topic. We're all prone to those, and need to keep in mind the eighteenth-century advice of Viscount Bolingbroke: "Truth lies within a little and certain compass, but error is immense." Rather, Feldman's errors in Poison Arrows are fundamental and imply a flawed scientific understanding of his material.

His topic is an important one but has a longer history than he seems to recognize. Curare, the paralytic arrow poison from South America, together with its derivatives and congeners, has unquestionably been a crucial element of the revolution in modern anaesthesia. But in the wider story of how nerve cells communicate with one another and with their target organs, such as muscles, glands and the heart, curare was never the central factor that Feldman - with an anaesthetist's understandable passion for these drugs - wants his readers to believe. The history of how nervecell communication came to be accepted as chemical in its operation, rather than electrical, has an earlier, more nebulous beginning than Feldman recognizes.

Until the late eighteenth century, conventional medical thinking assumed that good health follows from a proper balance of the four putative 'humours' of the body. Disease was a consequence of their imbalance, and we still talk of someone being in ill-humour. Then Alessandro Volta and Luigi Galvani discovered what they called 'animal electricity', and the era of what I call the 'dry brain' began. So, while pharmacologists pressed on with their potions and solutions, physiologists were, for the next century, fixated on electricity. Then Ramón y Cajal offered a revolutionary challenge. The nervous system, he asserted (on the basis of sublime microscopy), is composed of individual nerve cells (neurons) and is not a continuous network. In 1898, Charles Sherrington coined the term synapse for the intercellular links that were required to make Cajal's neurons operational, but the question remained contentious for some fifty years: is the connection electrical or chemical?

If only the physiologists had taken greater notice of their pharmacological colleagues, including Claude Bernard, who did important work with curare, as Feldman tells with some prolixity. In fact, it was an Austrian-based pharmacologist, Otto Loewi, who published

\section{Targeting the nervous system: darts dipped in the toxin curare are used by hunters in South America.}

the first convincing demonstration of chemical neurotransmission in 1921. Feldman tells little of this, favouring instead his fellow Briton Henry Dale, who shared a Nobel prize with Loewi. Feldman consistently misspells the term that Loewi chose for this transmitter, Vagusstoff ("Vagus nerve material"), as "vagusstuff".

That is only one of innumerable errors in this book, which betray what seems to be hasty writing and shoddy editing. No less important, Feldman rarely rises to the challenge of presenting an important scientific story. This is regrettable because many of today's therapeutic (and abused) drugs act by influencing chemical transmission between cells, either by modifying the production or disposal of the relevant chemicals or by influencing the sensitivity of the target cells to those transmitters. They symbolize the rehabilitation of the 'wet brain'.

A clear chemical understanding is necessary for both the research worker and the storyteller. Feldman's chemistry seems remarkably meagre. He refers to sodium and potassium molecules as often as he calls them ions, so it is no surprise that subtle matters, such as the importance of molecular affinities in driving reactions, are presented maladroitly. Just as bad, he seems not to recognize that when he and other anaesthetists measure muscular contractions in curarized patients or volunteers, this is an exceedingly indirect (and potentially fallacious) means of judging how much acetylcholine - the relevant transmitter - has been released from the nerve. It is also a poor guide of the sensitivity to it of the crucial receptor molecules in the target muscle. The essential problem with this analysis is that the transmission has an enormous 'safety factor': far more molecules of acetylcholine are released than the minimum required to generate the electrical signal that will, in turn, trigger the muscle contraction. It is akin to giving someone about $\$ 100$ for a $\$ 15$ train fare and then later trying to judge the amount of money in his pocket from the evidence of whether he actually bought a ticket or not. Even worse is trying to base a plausible financial theory simply on whether or not he's on the train.

Feldman is undeterred by such details. He seems, for example, quite unaware of the fact that there are two distinct classes of receptor molecule for acetylcholine. And he overplays the importance of this transmitter in the operations of the nervous system.

The history of curare is important for several reasons, principally because this chemical, in tandem with the development of safer anaesthetic drugs, is the real reason for the success story of modern surgery. It still awaits its Edward Gibbon.

John Carmody is a neuroscientist and writer at the University of New South Wales in Sydney,

Australia. 